\title{
Pengaruh Kualitas Produk, Harga Produk, Promosi Dan Layanan Purna Jual Terhadap Keputusan Pembelian Sepeda Motor Honda (Type Beat Mathic) (Studi Kasus Pada Siswa Smk Al Basthomi Loceret Nganjuk
}

\author{
Afiff Yudha Tripariyanto ${ }^{(1)}$, Lukmandono ${ }^{(2)}$ \\ ${ }^{(1,2)}$ Magister Teknik Industri, Institut Adhitama Surabaya \\ Email: afiff@unik-kediri.ac.id ${ }^{(1)}$
}

\begin{abstract}
Abstrak
Dengan zaman yang semakin canggih, perusahaan otomotif terutama dibidang sepeda motor harus dapat menentukan strategi pemasaran yang tepat agar usahanya dapat bertahan dan memenangi persaingan. Banyak faktor yang menjadi pertimbangan konsumen sebelum membeli suatu produk yaitu dipengaruhi oleh faktor promosi yang kurang efektif, harga yang lebih mahal dibandingkan harga yang ditawarkan pesaing, kualitas produk yang masih banyak kekurangan dan juga layanan purna jual yang kurang memberikan kepuasan kepada pelanggan. Tujuan dari penelitian ini adalah untuk mengetahui dan menguji pengaruh kualitas produk, harga, promosi dan layanan purna jual terhadap keputusan pembelian sepeda motor Honda Beat mathic dikalangan siswa Smk Al Bashtomi Loceret Nganjuk. Penelitian ini merupakan penelitian yang berjenis deskriptif, yaitu penelitian yang menggambarkan obyek-obyek yang berhubungan untuk pengambilan keputusan yang bersifat umum. Populasi dalam penelitian ini adalah Siswa SMK yang membeli sepeda motor Honda. Sampel dalam penelitian ini adalah 100 Siswa SMK AL-BASTHOMI Loceret Nganjuk yang membeli sepeda motor Honda yang diambil secara accidental sampling. Pengumpulan datanya dilakukan dengan menggunakan kuesioner. Hasil pengujian secara parsial membuktikan bahwa empat variabel independen yaitu kualitas produk, harga, promosi dan layanan purna jual mempunyai pengaruh positif dan signifikan terhadap variabel.
\end{abstract}

Kata kunci: harga produk, keputusan pembelian, kualitas produk, layanan purna jual, promosi

\begin{abstract}
With increasingly sophisticated times, automotive companies, especially in the field of motorcycles must be able to determine the right marketing strategy so that the business can survive and win the competition. Many factors are considered by consumers before buying a product that is influenced by factors that are less effective promotion, a price that is more expensive than the price offered by competitors, the quality of the product that is still lacking and also after-sales service that does not provide customer satisfaction. The purpose of this study was to determine and test the effect of product quality, price, promotion and after-sales service on purchasing decisions of Honda Beat Mathic motorcycles among students of Smk Al Bashtomi Loceret Nganjuk. This research is a descriptive type of research, namely research that describes objects that are related to general decision making. The population in this study were vocational students who bought Honda motorbikes. The sample in this study were 100 students of SMK Al-BASTHOMI Loceret Nganjuk who bought Honda motorcycles taken by accidental sampling. Data collection is done by using a questionnaire. The partial test results prove that four independent variables namely
\end{abstract}


product quality, price, promotion and after sales service have a positive and significant effect on the variable.

Keyword : product prices, purchasing decisions, product quality, after sales service, promotions

\section{Pendahuluan}

Di Era Globalisasi ini semakin berkembangnya kemajuan Teknologi di berbagai bidang dan aspek terutama di bidang Otomotif menyebabkan Tingkat persaingan dunia perdagangan Otomotif di Indonesia sangat ketat [1],[2],[3].Kebutuhan masyarakat indonesia akan alat transportasi kendaraan roda dua dewasa ini semakin bertambah setiap tahunnya. Sepeda motor merupakan alat transportasi roda dua yang efisien,efektif dan ekonomis serta terjangkau oleh sebagian besar masyarakat indonesia salah satunya adalah merk Honda Beat type Matic merupakan sepeda motor injection yang paling diminati konsumen karena mempuyai keunggulan keunggulan lebih dibandingkan kendaraan yang lain [4]. Pada dasarnya dengan semakin banyaknya pesaing maka semakin banyak pula pilihan bagi pelanggan untuk dapat memilih produk yang sesuai dengan apa yang menjadi harapannya [5],[6],[7],[8]. Sehingga konsekuensi dari perubahan tersebut adalah pelanggan menjadi lebih cermat dan pintar dalam menghadapi setiap produk yang diluncurkan dipasar [9].

Keputusan pembelian konsumen adalah membeli merek yang paling disukai, tetapi dua faktor dapat muncul antara niat untuk membeli dan keputusan pembelian, yaitu faktor sikap orang lain dan faktor situasi yang tidak diharapkan [10],[11],[12]. Pentingnya citra perusahaan dan layanan jasa kualitas sangat berpengaruh terhadap minat dan daya beli konsumen [13],[14]. Sikap Pengambilan keputusan oleh konsumen dalam membeli suatu barang maupun jasa tentunya berbeda, bergantung pada jenis keputusan pembelian yang diinginkannya [15],[16],[17],[18],[19]. Perusahaan Honda adalah salah satu perusahaan yang bergerak dalam bidang sektor produksi otomotif yang salah satunya memproduksi kendaraan roda dua dan empat [9],. Honda juga tidak terlepas akan persaingan yang semakin tajam khususnya dalam industri otomotif karena banyaknya perusahaan-perusahaan yang menghasilkan produk yang sejenis. Salah satu merk sepeda motor yang paling banyak diminati oleh masyarakat kususnya remaja saat ini adalah sepeda motor Honda Beat matic. Hasil pengamatan siswa SMK AL Bashtomi Mojosari Loceret Nganjuk lebih banyak menggunakan sepeda motor Honda tipe beat mathic karena produk tersbeut dalam melakukan iklan selalu loyal dalam artian melewati televisi, radio, majalah, media online dan pemasaran melalui pegawai atau dinamakan sales [20],[21].

Dari latar belakang diatas maka dalam Penelitian ini peneliti membentuk kerangka pemikiran yang meliputi 4 Variabel yang mempengaruhi keputusan pembelian sepeda motor Honda Beat type matic. Adapun kerangka pemikiranya sebagai berikut :

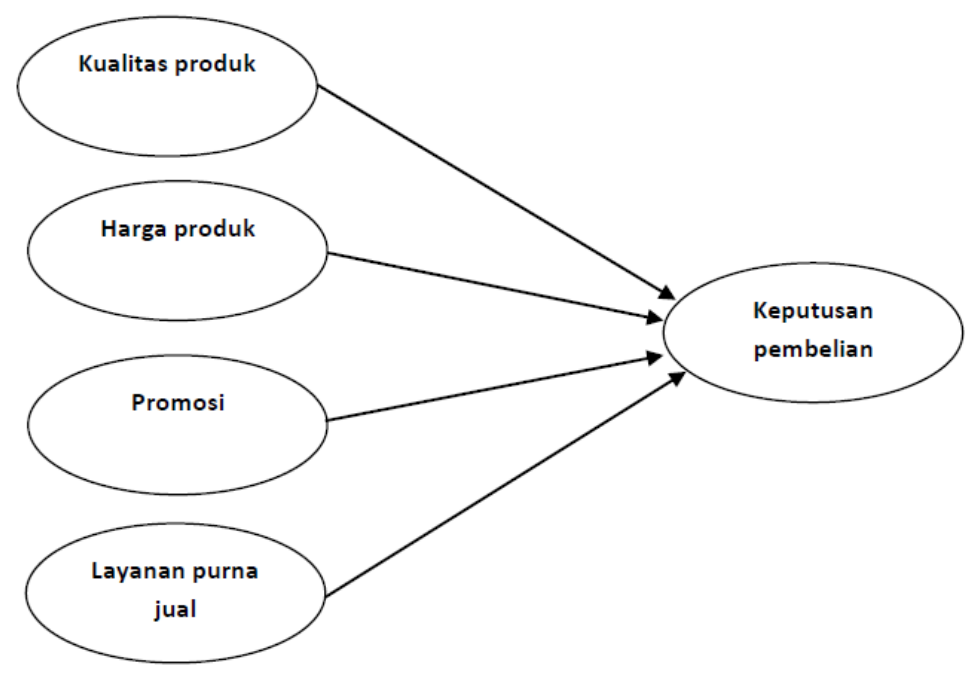

Gambar 1 Kerangka pemikiran teoritis 


\section{Metode Penelitian}

Dalam pelakasanaan penelitian ini digunakan sebagai berikut :

1. Waktu dan Obyek Penelitian

SMK Al-Bashtomi Mojosari Loceret Nganjuk adalah sebuah Sekolah Menengah Kejuruan dalam naungan Pondok Pesantren Mojosari Yayasan Nahdatul Ulama dusun Mojosari desa Ngepeh Kecamatan Loceret Kabupaten Nganjuk. Dalam penelitian ini, dilaksanakan pada tanggal 3-17 Januari 2016 dan kuisioner yang telah disebarkan adalah sebanyak 100 Siswa yang telah mengisi kuisioner tersebut

2. Teknik Pengumpulan Data

a. Penelitian Lapangan (Field Work Research) pengumpulan data primer yang dilakukan langsung ke obyek penelitian dengan Teknik [22],[23], :

1. Observasi yaitu pengamatan langsung ke obyek penelitian.

2. Interview yaitu wawancara dan tanya jawab kepada responden.

3. Penyebaran kuisioner yaitu pengumpulan data dengan memberikan beberapa pertanyaan

b. Studi kepustakaan (library research) pengumpulan data sekunder .

c. Dokumentasi berkaitan dengan obyek penelitian

3. Metode Analisis Data

Analisis data kualitatif adalah bentuk analisa yang berdasarkan dari data yang dinyatakan dalam bentuk uraian. Data kualitatif ini merupakan data yang hanya dapat diukur secara langsung [24],[25]. Analisis kuantitatif yaitu analisis yang digunakan terhadap data yang berwujud angkaangka dan cara pembahasannya dengan uji statistik :

Tabel 1 Definisi operasional variabel

\begin{tabular}{|c|c|c|c|}
\hline No. & Variabel & Definisi Operasional & Indikator \\
\hline 1. & $\begin{array}{l}\text { Kualitas } \\
\text { Produk } \\
\text { ( Product } \\
\text { Quality } \\
\text { (X1) }\end{array}$ & $\begin{array}{l}\text { Persepsi konsumen mengenai } \\
\text { kualitas produk }\end{array}$ & $\begin{array}{l}\text { 1. Keiritan bahan bakar } \\
\text { 2. Produk tidak mudah rusak } \\
\text { 3. Daya tahan mesin yang tangguh } \\
\text { 4. Penampilan produk yang menarik }\end{array}$ \\
\hline 2. & $\begin{array}{l}\text { Harga } \\
(\text { Price })(X 2)\end{array}$ & $\begin{array}{l}\text { Persepsi konsumen tentang } \\
\text { harga produk }\end{array}$ & $\begin{array}{l}\text { 1. Keterjangkauan harga } \\
\text { 2. Kesesuaian harga } \\
\text { 2. Daya saing harga } \\
\text { 3. Kesesuaian harga dengan manfaat }\end{array}$ \\
\hline 3. & $\begin{array}{l}\text { Promosi } \\
\text { (Promotion) } \\
(\mathrm{X} 3)\end{array}$ & $\begin{array}{l}\text { Kegiatan mengkombinasikan } \\
\text { informasi dari penjual kepada } \\
\text { pembeli atau pihak lain dalam } \\
\text { saluran untuk mempengaruhi } \\
\text { sikap dan perilaku. }\end{array}$ & $\begin{array}{l}\text { 1. Jangkauan promosi } \\
\text { 2. Kuantitas penayangan iklan di } \\
\text { media promosi } \\
\text { 3. Kualitas penyampaian pesan dalam } \\
\text { penayangan iklan dimedia promosi }\end{array}$ \\
\hline 4. & $\begin{array}{l}\text { Layanan } \\
\text { Purna Jual ( } \\
\text { Post Service } \\
\text { Sell) (X4) }\end{array}$ & $\begin{array}{l}\text { Persepsi konsumen mengenai } \\
\text { layanan purna jual }\end{array}$ & $\begin{array}{l}\text { 1. Ketersedian bengkel resmi } \\
\text { 2. Kemudahan mencari suku cadang } \\
\text { 3. Pelayanan ramah karyawan } \\
\text { 4. Penanganan keluhan konsumen. }\end{array}$ \\
\hline 5. & $\begin{array}{l}\text { Keputusan } \\
\text { pembelian } \\
\text { (Y) }\end{array}$ & $\begin{array}{l}\text { Serangkain unsur-unsur yang } \\
\text { mencerminkan keputusan } \\
\text { konsumen dalam } \\
\text { membeli,merupakan tahap } \\
\text { dimana konsumen dihadapkan }\end{array}$ & $\begin{array}{l}\text { 1. Kebutuhan dan keinginan suatu } \\
\text { produk } \\
\text { 2.Keinginan mencoba } \\
\text { 3. Kemantapan akan kualitas suatu } \\
\text { produk }\end{array}$ \\
\hline
\end{tabular}




\begin{tabular}{|l|l|l|l|}
\hline & & suatu pilihan untuk melakukan & 4.Keputusan pembelian ulang \\
\hline
\end{tabular}

Sumber : [26],[27],[28],[29],[30]

4. Alat Analisis dan Pengujian Hipotesis Dengan Software SPSS.

a. Uji Validitas dan Uji Reliabilitas

Pengujian validitas adalah suatu alat ukur mempunyai korelasi yang signifikan [31]. Sedangkan Uji reliabilitas adalah suatu indek yang menunjukkan sejauh mana hasil suatu penelitian pengukur dapat dipercaya [32].Hasil pengukuran dapat dipercaya atau reliable hanya apabila dalam beberapa kali pelaksanaan pengukuran terhadap kelompok subyek yang sama, selama aspek yang diukur dalam dari subjek memang belum berubah

1. Apabila $r$ hitung $>r$ tabel, maka item kuesioner tersebut valid.

2. Apabila $r$ hitung $<\mathrm{r}$ tabel, maka dapat dikatakan item kuesioner tidak valid

b. Uji Asumsi Klasik

Uji asumsi klasik bertujuan untuk mengetahui kondisi data yang dipergunakan dalam penelitian. Hal tersebut dilakukan agar diperoleh model analisis yang tepat [33].

c. Uji normalitas

Jika variable-variabel independen saling berkorelasi (diatas 0,9 ) dan nilai $\mathrm{R}^{2}$ yang dihasilkan oleh estimasi model regresi empiris sangat tinggi, dan nilai tolerance $<0,10$ atau sama dengan nilai VIF (Variance Inflation Factor) > 10 maka mengindikasikan adanya multikolinieritas [34].

d. Uji Parsial (Uji T)

Uji T (uji parsial) ini digunakan untuk mengetahui masing-masing Variabel bebasnya secara sendiri sendiri berpengaruh secara serempak terhadap Variabel terikatnya. Untuk mengetahui signifikan atau tidak maka digunakan Probability sebesar 5\% $(\mathrm{a}=0,05)$ dengan aturan sebagai berikut :

1. Jika Sig > a ( 0,05) maka H0 diterima dan H1 ditolak.

2. Jika Sig $<$ a $(0,05)$ maka H0 ditolak H1 diterima

e. Koefisien Determinan $\left(\mathrm{R}^{2}\right)$

Koefisien determinan $\left(\mathrm{R}^{2}\right)$ dimaksudkan untuk mengetahui tingkat ketepatan paling baik dalam analisis regresi, dimana hal yang ditunjukkan oleh besarnya koefisiensi determinasi $\left(\mathrm{R}^{2}\right)$ antara 0 (nol) dan 1 (satu).

\section{Hasil dan Pembahasan}

Dari pengolahan data yang sudah didapatkan berikut hasil dari penelitian :

Tabel 2 Hasil tanggapan responden terhadap variabel Kualitas Produk

\begin{tabular}{|c|c|c|c|c|c|c|c|c|}
\hline \multirow{2}{*}{$\begin{array}{c}\text { Item } \\
\text { Pertanyaan }\end{array}$} & \multirow[t]{2}{*}{$\mathrm{N}$} & \multicolumn{5}{|c|}{ Tanggapan } & \multirow[t]{2}{*}{ Mean } & \multirow{2}{*}{$\begin{array}{c}\text { Keterang } \\
\text { an }\end{array}$} \\
\hline & & STS & TS & $\mathrm{N}$ & $\mathrm{S}$ & SS & & \\
\hline X1_1 & 100 & - & 5 & 22 & 67 & 7 & 3.74 & Baik \\
\hline X1_2 & 100 & - & 8 & 25 & 46 & 21 & 3.80 & Irit \\
\hline X1_3 & 100 & - & 5 & 23 & 58 & 14 & 3.81 & Mudah \\
\hline X1_4 & 100 & - & 8 & 30 & 54 & 8 & 3.62 & Nyaman \\
\hline X1_5 & 100 & - & 13 & 36 & 45 & 6 & 3.44 & Menarik \\
\hline X1_6 & 100 & - & 5 & 36 & 45 & 14 & 3.68 & Aman \\
\hline X1_7 & 100 & - & 24 & 44 & 25 & 7 & 3.15 & Handal \\
\hline X1_8 & 100 & - & 21 & 55 & 18 & 6 & 3.09 & Baik \\
\hline X1_9 & 100 & - & 11 & 50 & 29 & 10 & 3.38 & Standard \\
\hline X1_10 & 100 & - & 3 & 41 & 45 & 11 & 3.64 & Standard \\
\hline X1_11 & 100 & - & 6 & 48 & 37 & 9 & 4.49 & Tanggap \\
\hline X1_12 & 100 & - & 5 & 24 & 52 & 19 & 3.85 & Menarik \\
\hline X1_13 & 100 & - & 4 & 15 & 57 & 24 & 4.01 & Menarik \\
\hline X1_14 & 100 & - & 3 & 40 & 45 & 12 & 3.66 & Baik \\
\hline
\end{tabular}




\begin{tabular}{|c|c|c|c|c|c|c|c|c|}
\hline X1_15 & 100 & - & 3 & 40 & 43 & 14 & 3.68 & Baik \\
\hline \multicolumn{8}{|c|}{ Total rata-rata } \\
\hline
\end{tabular}

Tabel 3 Hasil tanggapan responden terhadap kualitas variabel harga

\begin{tabular}{|c|c|c|c|c|c|c|c|c|}
\hline \multirow{2}{*}{$\begin{array}{c}\text { Item } \\
\text { Pertanyaan }\end{array}$} & \multirow[t]{2}{*}{$\mathrm{N}$} & \multicolumn{5}{|c|}{ Tanggapan } & \multirow[t]{2}{*}{ Mean } & \multirow[t]{2}{*}{ Keterangan } \\
\hline & & STS & $\mathrm{TS}$ & $\mathrm{N}$ & $\mathrm{S}$ & SS & & \\
\hline X2_1 & 100 & - & 9 & 57 & 28 & 6 & 3.31 & Terjangkau \\
\hline $\mathrm{X} 2 \_2$ & 100 & 2 & 13 & 46 & 37 & 2 & 3.24 & Sesuai \\
\hline $\mathrm{X} 23$ & 100 & 3 & 18 & 52 & 21 & 6 & 3.09 & Murah \\
\hline $\mathrm{X} 2 \_4$ & 100 & 2 & 22 & 43 & 29 & 4 & 3.11 & Lebih Murah \\
\hline $\mathrm{X} 2 \_5$ & 100 & - & 2 & 33 & 50 & 15 & 3.78 & Sesuai \\
\hline X3_6 & 100 & - & 9 & 38 & 40 & 18 & 3.57 & Bersaing \\
\hline $\mathrm{X} 2 \_7$ & 100 & 1 & 5 & 43 & 42 & 9 & 3.53 & Manfaat \\
\hline & & & & & & & 3.37 & Murah \\
\hline
\end{tabular}

Tabel 4 Hasil Tanggapan Responden Terhadap Variabel Promosi

\begin{tabular}{|c|c|c|c|c|c|c|c|c|}
\hline \multirow{2}{*}{$\begin{array}{c}\text { Item } \\
\text { Pertanyaan }\end{array}$} & \multirow[t]{2}{*}{$\mathrm{N}$} & \multicolumn{5}{|c|}{ Tanggapan } & \multirow[t]{2}{*}{ Mean } & \multirow[t]{2}{*}{ Keterangan } \\
\hline & & STS & TS & $\mathrm{N}$ & $\mathrm{S}$ & SS & & \\
\hline X3_1 & 100 & - & 2 & 18 & 55 & 25 & 4.03 & Iklan tv \\
\hline $\mathrm{X} 3 \_2$ & 100 & - & 13 & 30 & 48 & 9 & 3.53 & $\begin{array}{l}\text { Iklan } \\
\text { majalah }\end{array}$ \\
\hline X3_3 & 100 & 7 & 14 & 30 & 44 & 5 & 3.26 & Radio \\
\hline X3_4 & 100 & - & 4 & 24 & 43 & 23 & 3.03 & Karyawan \\
\hline$\times 3 \_5$ & 100 & 2 & 15 & 49 & 23 & 11 & 2.26 & Konsumen \\
\hline X3_6 & 100 & 1 & 11 & 41 & 38 & 9 & 3.43 & Produk \\
\hline X3_7 & 100 & 2 & 10 & 59 & 24 & 5 & 3.20 & Insentif \\
\hline X3_8 & 100 & 5 & 8 & 35 & 40 & 12 & 3.46 & Sponsor \\
\hline X3_9 & 100 & 4 & 27 & 37 & 27 & 5 & 3.02 & Teman \\
\hline X3_10 & 100 & 2 & 11 & 36 & 40 & 11 & 3.47 & Pemasaran \\
\hline \multicolumn{7}{|c|}{ Total rata-rata } & 3.37 & Setuju \\
\hline
\end{tabular}

Tabel 5 Hasil Tanggapan Responden Terhadap Variabel Layanan Purna Jual

\begin{tabular}{|c|c|c|c|c|c|c|c|c|}
\hline \multirow{2}{*}{$\begin{array}{c}\text { Item } \\
\text { Pertanyaan }\end{array}$} & \multirow[t]{2}{*}{$\mathrm{N}$} & \multicolumn{5}{|c|}{ Tanggapan } & \multirow[t]{2}{*}{ Mean } & \multirow[t]{2}{*}{ Keterangan } \\
\hline & & STS & TS & $\mathrm{N}$ & $\mathrm{S}$ & SS & & \\
\hline X4_1 & 100 & 1 & 4 & 28 & 49 & 18 & 3.79 & Garansi \\
\hline X4_2 & 100 & - & 3 & 30 & 52 & 15 & 3.79 & Mudah \\
\hline X4_3 & 100 & - & 2 & 37 & 47 & 13 & 3.70 & Keluhan \\
\hline X4_4 & 100 & 1 & 2 & 27 & 49 & 21 & 3.87 & Onderdil \\
\hline X4_5 & 100 & 3 & 5 & 28 & 38 & 26 & 3.79 & Mudah \\
\hline \multicolumn{7}{|c|}{ Total rata-rata } & 3.79 & Setuju \\
\hline
\end{tabular}

Tabel 6 Hasil Tanggapan Responden Terhadap Variabel Keputusan Pembelian

\begin{tabular}{|l|l|l|l|l|l|c|l|l|}
\hline Item & \multirow{2}{*}{ Pertanyaan } & & \multicolumn{7}{|c|}{ Tanggapan } & Mean & Keterangan \\
\cline { 3 - 8 } & & STS & TS & N & S & SS & & \\
\hline Y_1 & 100 & - & 3 & 56 & 39 & 2 & 3.40 & Setuju \\
\hline Y_2 & 100 & - & - & 55 & 43 & 2 & 3.47 & Setuju \\
\hline Y_3 & 100 & - & 2 & 41 & 52 & 5 & 3.60 & Setuju \\
\hline Y_4 & 100 & - & 2 & 38 & 49 & 11 & 3.69 & Setuju \\
\hline \multicolumn{7}{|c|}{ Total rata-rata } \\
\hline
\end{tabular}


Tabel 7 Uji Validitas Variabel Kualitas Produk (X1)

\begin{tabular}{|c|c|c|c|c|}
\hline Item & Validitas (Angka korelasi) & $\mathrm{R}_{\text {table }}$ & Probabilitas & Hasil Uji \\
\hline X1.1 & 0.351 & 0.1285 & 0.000 & Valid \\
X1.2 & 0.671 & 0.1285 & 0.000 & Valid \\
X1.3 & 0.308 & 0.1285 & 0.002 & Valid \\
X1.4 & 0.506 & 0.1285 & 0.000 & Valid \\
X1.5 & 0.428 & 0.1285 & 0.000 & Valid \\
X1.6 & 0.514 & 0.1285 & 0.000 & Valid \\
X1.7 & 0.591 & 0.1285 & 0.000 & Valid \\
X1.8 & 0.518 & 0.1285 & 0.000 & Valid \\
X1.9 & 0.614 & 0.1285 & 0.000 & Valid \\
X1.10 & 0.586 & 0.1285 & 0.000 & Valid \\
X1.11 & 0.396 & 0.1285 & 0.000 & Valid \\
X1.12 & 0.597 & 0.1285 & 0.000 & Valid \\
X1.13 & 0.563 & 0.1285 & 0.000 & Valid \\
X1.14 & 0.440 & & & Valid \\
X1.15 & 0.528 &
\end{tabular}

Tabel 8 Uji Validitas Variabel Harga (X2)

\begin{tabular}{|c|c|c|c|c|}
\hline Item & Validitas (Angka Korelasi) & $\mathrm{R}_{\text {table }}$ & Probabilitas & Hasil Uji \\
\hline X2.1 & 0.640 & 0.1285 & 0.000 & Valid \\
X2.2 & 0.597 & 0.1285 & 0.000 & Valid \\
X2.3 & 0.736 & 0.1285 & 0.002 & Valid \\
X2.4 & 0.699 & 0.1285 & 0.000 & Valid \\
X2.5 & 0.651 & 0.1285 & 0.000 & Valid \\
X2.6 & 0.438 & 0.1285 & 0.000 & Valid \\
X2.7 & 0.498 & 0.1285 & 0.000 & Valid \\
\hline
\end{tabular}

Tabel 9 Uji Validitas Variabel Promosi (X3)

\begin{tabular}{|c|c|c|c|c|}
\hline Item & Validitas (Angka korelasi) & $\mathrm{R}_{\text {table }}$ & Probabilitas & Hasil Uji \\
\hline X3.1 & 0.499 & 0.1285 & 0.000 & Valid \\
X3.2 & 0.492 & 0.1285 & 0.000 & Valid \\
X3.3 & 0.460 & 0.1285 & 0.002 & Valid \\
X3.4 & 0.594 & 0.1285 & 0.000 & Valid \\
X3.5 & 0.603 & 0.1285 & 0.000 & Valid \\
X3.6 & 0.587 & 0.1285 & 0.000 & Valid \\
X3.7 & 0.494 & 0.1285 & 0.000 & Valid \\
X3.8 & 0.526 & 0.1285 & 0.000 & Valid \\
X3.9 & 0.400 & 0.1285 & 0.000 & Valid \\
X3.10 & 0.452 & 0.000 & Valid \\
\hline
\end{tabular}

Tabel 10 Uji Validitas Variabel Layanan Purna jual (X4)

\begin{tabular}{|c|c|c|c|c|}
\hline Item & Validitas (Angka korelasi) & $\mathrm{R}_{\text {table }}$ & Probabilitas & Hasil Uji \\
\hline X4.1 & 0.595 & 0.1285 & 0.000 & Valid \\
X4.2 & 0.670 & 0.1285 & 0.000 & Valid \\
X4.3 & 0.628 & 0.1285 & 0.002 & Valid \\
X4.4 & 0.740 & 0.1285 & 0.000 & Valid \\
X4.5 & 0.666 & 0.1285 & 0.000 & Valid \\
\hline
\end{tabular}


Tabel 11 Uji Reliabilitas

\begin{tabular}{|c|c|c|}
\hline Variabel & Nilai Alpha & Keterangan \\
\hline Kualitas Produk & 0.793 & Reliabel \\
\hline Harga & 0.716 & Reliabel \\
\hline Promosi & 0.680 & Reliabel \\
\hline Layanan purnajual & 0.668 & Reliabel \\
\hline Keputusan pembelian & 0.615 & Reliabel \\
\hline
\end{tabular}

Tabel 12 Uji Multikolonieritas

\begin{tabular}{|l|l|l|}
\hline Variabel & Tolerance & VIF \\
\hline Kualitas produk & .697 & 1.434 \\
\hline Harga & .733 & 1.365 \\
\hline Promosi & .723 & 1.838 \\
\hline Layanan purnajual & .783 & 1.277 \\
\hline
\end{tabular}

Tabel 13 Hasil uji Autokorelasi

\begin{tabular}{|l|l|l|l|l|l|}
\hline $\begin{array}{l}\text { Mode } \\
1\end{array}$ & $\mathrm{R}$ & $\begin{array}{l}\mathrm{R} \\
\text { Square }\end{array}$ & $\begin{array}{l}\text { Adjusted R } \\
\text { Square }\end{array}$ & $\begin{array}{l}\text { Std. Error of } \\
\text { the Estimate }\end{array}$ & $\begin{array}{l}\text { Durbin- } \\
\text { Watson }\end{array}$ \\
\hline 1 & $.797 \mathrm{a}$ & .635 & .620 & .25713 & 1.560 \\
\hline
\end{tabular}

Scatterplot

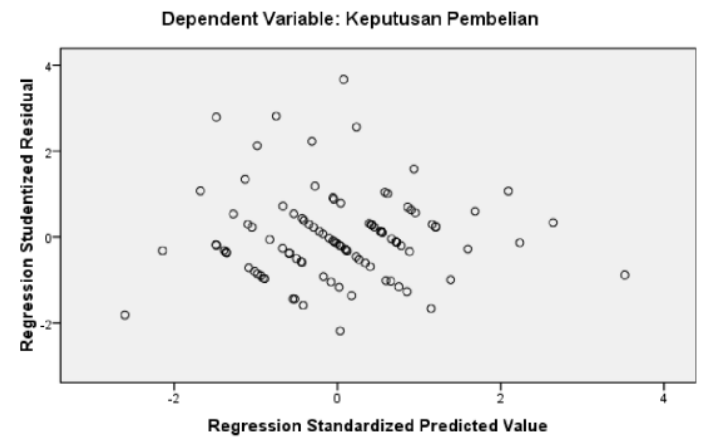

Gambar 2 Diagram Scatter Plot

Normal P-P Plot of Regression Standardized Residual

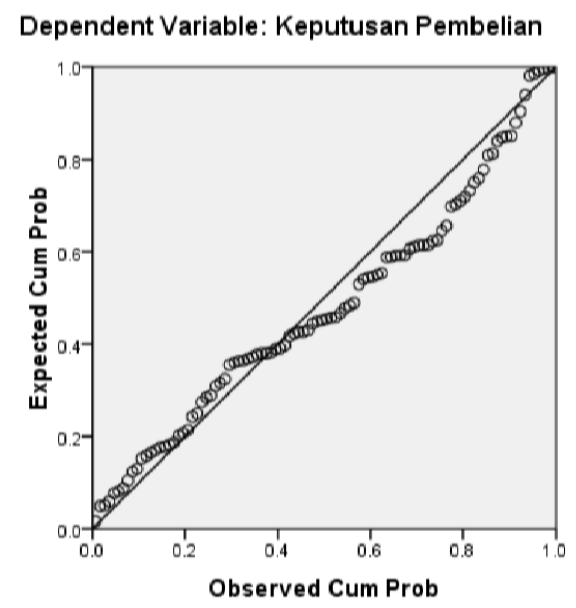

Gambar 3 P-Plot 
Tabel 14 Persamaan regresi

\begin{tabular}{|l|c|c|c|c|c|}
\hline \multirow{2}{*}{ Modal } & \multicolumn{2}{|c|}{$\begin{array}{c}\text { Unstandardized } \\
\text { Coefficient }\end{array}$} & $\begin{array}{c}\text { Standardized } \\
\text { Coefficients }\end{array}$ & $\mathrm{t}$ & Sig. \\
\cline { 2 - 5 } & $\mathrm{B}$ & Std. Error & Beta & & \\
\hline 1. (Constant) & .057 & .276 & & .206 & .837 \\
Kualitas produk & .383 & .079 & .358 & 4.822 & .000 \\
Harga & .279 & .063 & .323 & 4.455 & .000 \\
Promosi & .201 & .067 & .217 & 2.985 & .004 \\
Layanan Purna Jual & .129 & .054 & .166 & 2.367 & .020 \\
\hline
\end{tabular}

Tabel 15 Uji Parsial (Uji T)

\begin{tabular}{|c|c|c|c|}
\hline Variable & $\mathrm{T}_{\text {hitung }}$ & Signifikansi & Keterangan \\
\hline Kualitas produk & 4.822 & .000 & H1 diterima \\
\hline Harga & 4.455 & .000 & H2 diterima \\
\hline Promosi & 2.985 & .004 & H3 diterima \\
\hline Layanan purnajual & 2.367 & .020 & H4 diterima \\
\hline
\end{tabular}

\section{Kesimpulan}

Berdasarkan hasil pengujian dan pembahasan tentang pengaruh kualitas produk, harga produk, promosi dan layanan purna jual maka dapat diambil kesimpulan sebagai berikut :

$$
\mathrm{Y}=0,057+0,383 \mathrm{X} 1+0,279 \mathrm{X} 2+0,201 \mathrm{X} 3+0,129 \mathrm{X} 4
$$

1. Hasil pengujian secara parsial menunjukkan bahwa variabel kualitas produk mempunyai pengaruh yang positif dan searah terhadap keputusan pembelian sepeda motor Honda type beat matic hal ini buktikan dari hasil pengujian thitung kualitas produk 4.822 dan nilai signifikansi $0.000<0.05$. Hasil pengujian koefisien determinasi menunjukkan bahwa variabel kualitas produk mempunyai pengaruh keputusan pembelian motor honda beat matic, hal ini ditunjukkan nilai korelasi parsial sebesar 0,443 sehingga determinasi parsial $\left(\mathrm{r}^{2}\right)=0,1962$ atau sebesar $19.62 \%$.

2. Hasil pengujian secara parsial menunjukkan bahwa variabel harga mempunyai pengaruh yang positif dan searah terhadap keputusan pembelian sepeda motor Honda type beat matic hal ini buktikan dari hasil pengujian thitung harga 4,455 dan nilai signifikansi $0.000<0.05$.

3. Hasil pengujian secara parsial menunjukkan bahwa variabel promosi mempunyai pengaruh yang positif dan searah terhadap keputusan pembelian sepeda motor Honda type beat matic hal ini buktikan dari hasil pengujian thitung promosi 2.985 dan nilai signifikansi $0.004<0.05$.

4. Hasil pengujian secara parsial menunjukkan bahwa variabel layanan purna jual mempunyai pengaruh yang positif dan searah terhadap keputusan pembelian sepeda motor Honda type beat matic hal ini buktikan dari hasil pengujian thitung layanan purnajual 2.367 dan nilai signifikansi $0.000<0.05$.

5. Hasil pengujian koefisien Determinasi menunjukkan bahwa variabel kualitas produk mempunyai pengaruh terhadap keputusan pembelian sepeda motor honda beat matic, hal ini ditunjukkan nilai korelasi parsial sebesar 0,443 sehingga determinasi parsial $\left(\mathrm{r}^{2}\right)=0,1962$ atau sebesar $19.62 \%$

\section{Daftar Pustaka}

[1] C. A. Rompas, V. P. K. Lengkong, and M. M. Karuntu, “Analisis Bauran Pemasaran Terhadap Keputusan Pembelian Mobil Daihatsu Ayla Pada Pt. Astra International Tbk. Daihatsu Cabang Martadinata Manado," 3Fakultas Ekon. dan Bisnis, Jur. Manaj. Univ. Sam Ratulangi, vol. 5, no. 3, pp. 4505-4514, 2017.

[2] K. F. Ferine and H. Sembiring, Manajemen Sumber Daya Manusia Strategi Pemberdayaan UMKM. Pendidikan Deepublish, 2018. 
[3] S. P. Raj, B.-D. Rhee, and K. Sivakumar, "Manufacturer adoption of a unilateral pricing policy in a multi-channel setting to combat customer showrooming," J. Bus. Res., vol. 110, pp. 104$118,2020$.

[4] W. Nuriyanti, "Segmentasi Pasar Berdasarkan Demografi Dalam Memilih Sepeda Motor Matic Di Wilayah Depok," Util. J. Ilm. Pendidik. dan Ekon., 2017.

[5] E. Suryonaningsih, "Effect of Price and Image Brand on Consumer Satisfaction," J. Manage., vol. 2, no. 2, 2016.

[6] F. Tjiptono and G. Chandra, Pemasaran Strategik edisi 3. ANDI, 2017.

[7] A. Rares, "THE EFFECT OF THE PRICE, PROMOTION, LOCATION, BRAND IMAGE AND QUALITY PRODUCTS TOWARDS THE PURCHASE DECISION OF CONSUMERS AT BENGKEL GAOEL STORE MANADO TOWN SQUARE,” J. EMBA, vol. 15, no. 2011, pp. 1506-1513, 2015.

[8] P. Kotler and G. Armstrong, Principles Of Marketing, 15th ed. Boston: Pearson UK, 2019, 2014.

[9] M. Andrew, "Honda's Global Flexifactory Network. Internasional Journal of Operations dan Production Management," Departeement of Management and Busines Studies,Birkbeck College. University of London,UK, 1994.

[10] P. Kotler and G. Armstrong, "Kotler \&amp; Armstrong, Principles of Marketing | Pearson," in Pearson, 2018.

[11] P. Kotler and K. L. Keller, Manajemen pemasaran Jilid 1. 2009.

[12] Z. Khoiriyah, E. Soegiarto, and S. E. Wibowo, "Pengaruh Atribut Produk terhadap Keputusan Pembelian Smartphoen Merek Samsung,” Fak. Ekon., vol. 1, 2014.

[13] D. Diniaty and Agusrinal, "Perancangan Strategi Pemasaran pada Produk Anyaman Pandan ( Studi Kasus : Home Industry Saiyo Sakato Di Kenagarian Padang Laweh Kecamatan Koto Vii Kabupaten Sawahlunto Sijunjung )," J. Sains, Teknol. dan Ind., vol. 11, no. 2, pp. 175-184, 2014.

[14] A. Wihardias, "Analisis Kualitas Pelayanan Jasa Pada Jurusan Manajemen Bisnis Its Dengan Metode Servqual Dan QFD,” Sepuluh November Institute of Technology, 2015.

[15] P. Alan, "Research Themes, Concepts and Relationship: A study Internasional Journal of Service Industry Management," Int. J. Serv. Ind. Manag., vol. 19, no. 1, 2008.

[16] J. Sheth, A. Parvatiyar, and L. L. Berry, "Relationship Marketing of Services: Growing Interest, Emerging Perspectives," in Handbook of Relationship Marketing, 2014.

[17] A. Komari, "Pengaruh Lingkungan dan Kapasitas Manajerial Terhadap Keputusan Pendanaan Bagi Usaha Kecil Kerajinan di Jawa Timur," vol. 4, no. 1, 2017.

[18] M. Nafali and D. Soepeno, "ANALISIS PENGARUH FAKTOR-FAKTOR PERILAKU KONSUMEN TERHADAP KEPUTUSAN PEMBELIAN MAKANAN MIE INSTANMEREK INDOMIE (Studi Kasus Pada Mahasiswa Fakultas Ekonomi Dan Bisnis, Fakultas Ilmu Sosial dan Politik,dan Fakultas Pertanian Universitas Sam Ratulangi Manad," J. Ris. Ekon. Manajemen, Bisnis dan Akunt., vol. 4, no. 4, pp. 984-992, 2016.

[19] D. Halaj and Y. Brodrechtova, "Marketing decision making in the forest biomass market: The case of Austria, Finland and Slovakia," For. Policy Econ., vol. 97, pp. 201-209, Dec. 2018.

[20] D. S. Martin, B. L. Bourdeau, and J. Stephan, "Measuring the effectiveness of facility naming rights sponsorships," J. Bus. Res., vol. 110, pp. 51-64, 2020. 
[21] S. M. Lee, P. Jiraporn, and H. Song, "Customer concentration and stock price crash risk," J. Bus. Res., vol. 110, pp. 327-346, 2020.

[22] P. D. Sugiyono, metode penelitian kuantitatif, kualitatif,dan R\&D. 2016.

[23] A. Maksum, "Pengumpulan data," J. Metod. pengumpulan data, 2012.

[24] I. Agusta, "Teknik Pengumpulan dan Analisis Data Kualitatif," J. Stud. Komun. dan Media, vol. 02, no. 1998, pp. 1-11, 2014.

[25] H. Hasanah, "TEKNIK-TEKNIK OBSERVASI (Sebuah Alternatif Metode Pengumpulan Data Kualitatif Ilmu-ilmu Sosial)," At-Taqaddum, vol. 8, no. 1, p. 21, 2017.

[26] P. Kotler, "pengaruh harga,kualitas produk dan citra merk terhadap keputusan pembelian,” pp. 9-30, 2015.

[27] N. Laely, "Analisis Pengaruh Kepercayaan dan Harga Terhadap Loyalitas Pelanggan Dimediasi Kepuasan Pada PT. Telkomsel di Kota Kediri," Ilmu Ekon. Manaj., vol. 3, no. 2, pp. 61-74, 2016.

[28] M. L. Hedynata and W. E.D.Radianto, "Strategi Promosi Dalam Meningkatkan Penjualan Luscious Chocolate Potato Snack," J. Manaj., 2016.

[29] R. A. M. Puteri and M. I. Alrosyid, "Perencanaan Perawatan Air Compressor Unit Untuk Komponen Air Quick Couplings Dengan Metode Reliability Centered Maintenance Di Pt Astra International Tbk - Tso Cabang Salemba," J. PASTI, vol. 9, no. 2, pp. 129-137, 2015.

[30] J. Marcelina and B. T. B, "Pengaruh Marketing Mix (7P) Terhadap Keputusan Pembelihan Pada Guest House Di Surabaya," Progr. Manaj. Perhotelan, Fak. Ekon. Univ. Kristen Petra, Surabaya, Indones., no. 2015, 2016.

[31] P. D, "Belajar Cepat Olah Data Statistik dengan SPSS," in Uji Validitas dan Reliabilitas, 2012.

[32] Suliyanto, Metode Penelitian Bisnis, 1st ed. Andi Publisher, 2018.

[33] A. D. . Janie, "Statistik Deskripstif dan Regresi Linier Berganda dengan SPSS," in Statistik Deskripstif dan Regresi Linier Berganda dengan SPSS, 2012.

[34] A. Kristanto and S. C. Widodo, "Perancangan Ulang Alat Perontok Padi yang Ergonomis untuk Meningkatkan Produktivitas dan Kualitas Kebersihan Padi," J. Ilm. Tek. Ind., vol. 14, no. 1, pp. 78-85, 2015. 